\title{
PENGARUH KITOSAN DAN Trichoderma sp. TERHADAP KEPARAHAN PENYAKIT ANTRAKNOSA (Colletotrichum capsici (Syd.) Butl. et Bisby) PADA BUAH CABAI (Capsicum annuum L.)
}

\author{
Edy Sarwono, Muhammad Nurdin \& Joko Prasetyo \\ Jurusan Agroteknologi, Fakultas Pertanian Universitas Lampung \\ Jl. Prof. Soemantri Brodjonegoro, No. 1, Bandar Lampung 35145 \\ E-mail: edy_s20@yahoo.co.id
}

\begin{abstract}
ABSTRAK
Penelitian ini bertujuan untuk mengetahui pengaruh kitosan dan Trichoderma sp. terhadap keparahan penyakit antraknosa (C. capsici) pada buah cabai (C. апnиит L.). Hipotesis yang diajukan ialah bahwa aplikasi kitosan dan Trichoderma sp. dapat menekan keparahan penyakit antraknosa pada buah cabai, terdapat perbedaan pengaruh antara perlakuan kitosan, dan Trichoderma sp. terhadap keparahan penyakit antraknosa pada buah cabai, dan kitosan tidak berbeda jauh dengan fungisida berbahan aktif kaptan dalam menekan keparahan penyakit antraknosa pada buah cabai. Penelitian ini dilakukan di Laboratorium Penyakit Tumbuhan Fakultas Pertanian Universitas Lampung dari bulan Mei hingga Agustus 2012. Percobaan ini terdiri atas 5 perlakuan, yaitu kontrol (P1), kitosan (P2), kitosan+Trichoderma sp. (P3), Trichoderma sp. (P4), dan fungisida berbahan aktif kaptan (P5). Perlakuan disusun dalam Rancangan Acak Lengkap (RAL) dengan masing-masing perlakuan 3 ulangan. Data yang diperoleh dianalisis dengan sidik ragam kemudian untuk melihat perbedaan antar perlakuan menggunakan Uji Beda Nyata Terkecil (BNT). Hasil penelitian menunjukkan bahwa kitosan, kitosan+Trichoderma sp. dan fungisida sintetis berbahan aktif kaptan dapat menekan keparahan penyakit antraknosa pada buah cabai. Trichoderma sp. saja tidak dapat menekan keparahan penyakit antraknosa pada buah cabai, dan pengaruh kitosan dalam menekan keparahan penyakit antraknosa pada buah cabai sebanding dengan fungisida sintetis berbahan aktif kaptan.
\end{abstract}

Kata kunci: Kaptan, kitosan, penyakit antraknosa, Trichoderma sp.

\section{PENDAHULUAN}

Cabai merupakan salah satu komoditas hortikultura andalan di Indonesia dan mempunyai nilai ekonomis tinggi. Namun dalam budidaya cabai tidak sedikit tantangan dan kendala yang dihadapi, khususnya masalah organisme pengganggu tanaman (OPT) yang dapat menurunkan kuantitas maupun kualitas produksi, bahkan dapat menggagalkan panen. Dalam upaya menyelamatkan tanaman dari serangan OPT, tidak jarang petani menerapkan berbagai cara pengendalian OPT yang sebetulnya tidak sesuai dengan ketentuan yang telah dianjurkan, misalnya penggunaan fungisida dan bahan kimia lainnya secara berlebihan.

Penyakit antraknosa pada tanaman cabai dapat disebabkan oleh cendawan Colletotrichum acutatum, C. gloeosporioides, atau C. capsici (Direktorat Perlindungan Hortikultura, 2010). Namun di beberapa negara penyakit ini dianggap sebagai dua penyakit, yang masing-masing disebabkan oleh satu jamur. Penyakit yang disebabkan oleh jamur Gloeosporium disebut antraknosa, sedangkan penyakit yang disebabkan oleh jamur Colletotrichum disebut busuk matang (ripe rot) (Semangun, 1989).
Penyakit antraknosa merupakan masalah serius bagi para petani cabai karena bisa menghancurkan panen hingga 20-90\% terutama pada saat musim hujan (Yusuf, 2010). Berdasarkan data yang diperoleh dari Laporan Tahunan BPTPH 2010 Provinsi Lampung, penyakit antraknosa yang menyerang tanaman cabai di Provinsi Lampung Tahun 2010 mencapai 511 ha (ringan - berat).

Petani biasanya menggunakan fungisida sintetik untuk mengendalikan penyakit antraknosa. Sebagian petani menggunakan fungisida sintetik yang belum sesuai dengan ketentuan yang dianjurkan. Penggunaan fungisida sintetik yang tidak sesuai dengan ketentuan dapat menimbulkan dampak negatif terhadap lingkungan. Untuk itu penggunaan fungisida sintetik harus ditekan sekecil mungkin dan sebagai penggantinya harus dicari bahan fungisida yang tidak berpengaruh negatif terhadap lingkungan dan manusia (Efri, 2010).

Kitosan dapat menghambat perkembangan spora, mengubah morfologi jamur, serta menginduksi enzim yang dapat digunakan sebagi pelindung buah. Kitosan dapat diaplikasikan pada buah dan sayur dengan cara dicelup atau disemprotkan (Yanti et al., 2009 dalam Widodo et al., 2013). 
Pemanfaatan Trichoderma sp. diharapkan dapat membantu pengendalian penyakit tanpa mengganggu kondisi lingkungan. Pengendalian hayati dengan menggunakan agensia hayati seperti Trichoderma sp. diharapkan dapat mengurangi ketergantungan terhadap fungisida sintetik dan dapat mengatasi dampak negatif dari pemakaiannya untuk pengendalian penyakit tanaman di Indonesia (Purwantisari dan Hastuti, 2009 dalam Ismail dan Tenrirawe, 2012).

\section{BAHAN DAN METODE}

Penelitian ini dilaksanakan di Laboratorium Penyakit Tumbuhan Jurusan Agroteknologi Bidang Proteksi Tanaman Fakultas Pertanian Universitas Lampung dari bulan Mei sampai Agustus 2012. Bahanbahan yang digunakan dalam penelitian ini adalah buah cabai sehat dan buah cabai yang terserang penyakit antraknosa, kentang, gula (sukrosa), agar batang, kitosan, asam asetat, Trichoderma sp., fungisida, aquades, larutan klorok dan alkohol 70\%. Alat-alat yang digunakan dalam penelitian ini adalah cawan petri, jarum ose, beaker glass, otoklaf, plastik tahan panas, alumunium foil, kertas saring, Bunsen, bor gabus, korek api, spidol, Erlenmeyer, kaca preparat, cover glass, spatula, gelas ukur, tissue, Laminar Air Flow, oven, timbangan, karet, nampan, toples, panci, dan kertas label.

Perlakuan penelitian ini disusun dalam Rancangan Acak Lengkap (RAL) yang terdiri dari 5 perlakuan termasuk kontrol dengan masing-masing tiga ulangan, setiap ulangan terdapat 5 buah cabai sehingga terdapat 15 satuan percobaan. Perlakuan terdiri dari kontrol (air steril), aplikasi kitosan, aplikasi Trichoderma sp., aplikasi kitosan yang dikombinasikan dengan Trichoderma sp. dan aplikasi fungisida berbahan aktif kaptan (pembanding).

Pembuatan Media PSA sebanyak 11 dibutuhkan $20 \mathrm{~g}$ agar batang yang telah dipotong-potong, $20 \mathrm{~g}$ gula pasir dan $200 \mathrm{~g}$ kentang. Kentang dipotong kecil-kecil lalu direbus di dalam 11 air kemudian ditambah gula pasir sambil diaduk, setelah itu rebusan disaring ke dalam tabung erlenmeyer ukuran 11 . Selanjutnya tabung erlenmeyer berisikan PSA tersebut disterilkan dengan otoklaf pada suhu $121^{\circ} \mathrm{C}$ dan tekanan $1 \mathrm{~atm}$ selama \pm 30 menit. Setelah sterilisasi selesai, media PSA didiamkan sampai hangat kuku kemudian ditambah $0,7 \mathrm{ml}$ asam laktat kemudian dituang ke dalam cawan petri secara aseptik.

Penyiapan biakan Colletotrichum capsici sebagai sumber inokulum disiapkan dengan cara memotong jaringan buah cabai yang sakit berikut jaringan sebelahnya yang masih sehat berbentuk segi empat berukuran 3-5 $\mathrm{mm}$. Potongan-potongan jaringan tersebut direndam dalam larutan $\mathrm{NaCl}$ 0,5\% selama 1530 detik lalu dibilas dengan aquades steril sebanyak tiga kali kemudian dikeringanginkan. Potongan buah cabai tersebut diletakkan pada media PSA secara aseptik, kemudian diinkubasi dalam suhu kamar. Biakan murni diperoleh setelah umur 3-5 hari, koloni jamur yang tumbuh dipotong bagian pinggirnya, selanjutnya diletakkan secara aseptik pada media PSA dan diinkubasi. Setelah didapat biakan murni jamur $C$. capsici kemudian dilakukan pengenceran untuk memperoleh kerapatan spora yang diperlukan untuk perlakuan, yaitu sebanyak 4 cawan biakan murni jamur C. capsici dicampur dengan $100 \mathrm{ml}$ aquades steril ke dalam gelas piala sehingga didapat kerapatan spora mencapai $1,37 \times 10^{6}$ spora $\mathrm{ml}^{-1}$.

Langkah pertama membuat biakan murni Trichoderma sp. dengan cara mengambil biakan jamur Trichoderma sp. secara aseptik dari tabung reaksi yang diperoleh dari Laboratorium Balai Proteksi Tanaman Gadingrejo, kemudian diletakkan pada media PSA, selanjutnya diinkubasi dalam suhu kamar. Suspensi Trichoderma sp. diperoleh dengan cara menambahkan $100 \mathrm{ml}$ aquades steril ke dalam gelas piala ditambah satu cawan petri jamur Trichoderma sp. sehingga didapat kerapatan spora mencapai $37 \times 10^{6}$ spora $\mathrm{ml}^{-1}$. Suspensi Trichoderma sp. dibagi menjadi 2, satu bagian untuk perlakuan Trichoderma sp. dan satu bagian lagi untuk perlakuan kitosan+Trichoderma sp.

Pembuatan larutan kitosan 2,5\% dibuat dengan cara melarutkan 2,5 g kitosan ke dalam $5 \mathrm{ml}$ asam asetat $0,5 \%$ ditambah akuades hingga $100 \mathrm{ml}$. Larutan asam asetat $0,5 \%$ dibuat dengan cara melarutkan $5 \mathrm{ml}$ asam asetat kedalam akuades hingga diperoleh volume 100 ml larutan (Widodo et al, 2013). Selanjutnya larutan kitosan dibagi menjadi 2, satu bagian untuk perlakuan kitosan dan satu bagian lagi untuk perlakuan kitosan+Trichoderma sp.

Penyiapan suspensi fungisida berbahan aktif kaptan dibuat dengan menggunakan bubuk fungisida kaptan 1,5 g dicampur dengan $100 \mathrm{ml}$ air aquades (sesuai dengan dosis yang tercantum pada kemasan fungisida). Buah cabai varietas keriting yang digunakan diperoleh dari pasar dalam keadaan bersih, sehat dan dikemas dalam plastik, kemudian cabai tersebut dicuci dengan air steril sampai bersih dan siap untuk digunakan penelitian.

Aplikasi dilakukan dengan cara merendam/ melumuri buah cabai sehat dengan masing-masing perlakuan kitosan, Trichoderma sp., kombinasi kitosan dengan Trichoderma spp., dan fungisida berbahan aktif kaptan. Buah cabai yang telah dilumuri dengan masing- 
masing bahan tersebut kemudian diinokulasi dengan jamur C. capsici dengan cara melumurkannya ke buah cabai tersebut. Buah cabai kemudian diinkubasi dalam toples yang diberi tisu yang dibasahi dengan air steril $10 \mathrm{ml}$ dan dialasi pipet/sedotan.

Pengamatan terhadap keparahan penyakit dilakukan pada 7, 11, dan 15 hari setelah perlakuan (hsp). Diperkirakan setelah 15 hari setelah perlakuan, buah cabai membusuk secara utuh. Menurut Karyatiningsih (1980), pengamatan intensitas penyakit (keparahan penyakit) yang disebabkan oleh cendawan yang menyerang tanaman dihitung menggunakan metode Townsend dan Heuberger, dengan rumus sebagai berikut:

$$
K P=\frac{\sum n \times v}{N \times V} \times 100 \%
$$

Keterangan:

$\mathrm{KP}=$ Keparahan penyakit

$\mathrm{n} \quad=$ Jumlah buah tiap kelas luas gejala

$\mathrm{v}=$ Nilai skor tiap luas gejala

$\mathrm{N}=$ Jumlah buah yang diamati

$\mathrm{V}=$ Skor tertinggi

\section{HASIL DAN PEMBAHASAN}

Gejala penyakit antraknosa pada buah cabai mulai terlihat pada hari ke 4 setelah perlakuan. Pada hari ke 15 gejala antraknosa semakin parah. Gejala antraknosa pada buah cabai sangat mudah dikenali dengan gejala awal bercak kecil dan berair seperti luka karena terkena sinar matahari (Gambar 1A). Busuk meluas hingga mencapai 3-4 cm pada buah cabai yang berukuran besar. Pada serangan lanjut yang sudah parah, gejala tersebut lebih jelas tampak seperti luka terbakar matahari dan berwarna antara merah tua sampai coklat menyala hingga warna hitam (Gambar 1B).

Pada pengamatan 15 hsp, keparahan penyakit antraknosa pada perlakuan Trichoderma sp. tidak berbeda nyata dengan kontrol. Keparahan penyakit antraknosa pada perlakuan kitosan + Trichoderma sp., kitosan dan kaptan berbeda nyata dengan kontrol. Pengaruh perlakuan Trichoderma sp. jika dibandingkan dengan kitosan + Trichoderma sp. tidak berbeda nyata dalam menekan keparahan penyakit antraknosa pada buah cabai. Akan tetapi, perlakuan kitosan+ Trichoderma sp. bisa dikatakan lebih baik dari perlakuan Trichoderma sp. dikarenakan pengaruh perlakuan Trichoderma sp. tidak berbeda nyata dengan kontrol dalam menekan keparahan penyakit antraknosa (Tabel 1). Keparahan penyakit pada perlakuan kitosan dibandingkan dengan fungisida sintetis berbahan aktif kaptan tidak berbeda nyata, sedangkan pengaruh perlakuan Trichoderma sp. dan kitosan + Trichoderma sp. berbeda nyata dengan perlakuan kaptan. Hal ini berarti pengaruh kitosan tidak berbeda dengan fungisida sintetis berbahan aktif kaptan dalam menekan keparahan penyakit antraknosa.

Perkembangan penyakit antraknosa pada buah cabai bervariasi, ada yang grafiknya agak landai dan ada yang grafiknya agak curam. Perkembangan penyakit antraknosa yang grafiknya agak curam adalah P1 (kontrol), P2 (kitosan), dan P4 (Trichoderma sp. ) dari 7 hsp-15hsp. sedangkan perkembangan penyakit antraknosa yang grafiknya agak landai adalah P3 (kitosan+ Trichoderma sp.) dan P5 (fungisida berbahan aktif kaptan) dari 7 hsp-15 hsp. Secara jelas perkembangan penyakit antraknosa pada buah cabai terlihat pada Gambar 2.

Meskipun dalam statistik kitosan saja lebih baik daripada kitosan+ Trichoderma sp., namun jika dilihat dari grafik dapat diketahui bahwa ketika kitosan bercampur dengan Trichoderma sp. ternyata kemampuan dalam menekan perkembangan penyakit antraknosa lebih baik daripada masing-masing sendiri.

Seperti telah diketahui dari penelitian Sugipriatini (2009) disebutkan bahwa kitin adalah polimer berantai lurus yang tersusun atas residu $\mathrm{N}$-asetilglukosamina
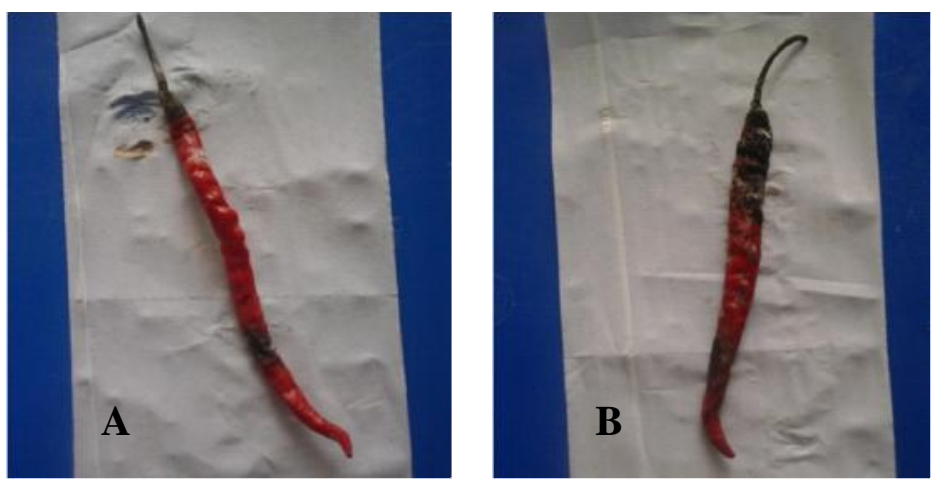

Gambar 1. Gejala penyakit antraknosa pada buah cabai (A) 7 hsp dan (B) 15 hsp. 
Tabel 1. Nilai tengah keparahan penyakit antraknosa pada buah cabai pada berbagai perlakuan.

\begin{tabular}{lc}
\hline \multicolumn{1}{c}{ Perlakuan } & Keparahan Penyakit (\%) pada 15 hsp \\
\hline P1. Kontrol (air steril) & $76,00 \mathrm{a}$ \\
P4. Trichoderma sp. & $66,67 \mathrm{ab}$ \\
P3. Kitosan + Trichoderma spp. & $46,67 \mathrm{bc}$ \\
P2. Kitosan & $45,33 \mathrm{bcd}$ \\
P5. Kaptan & $28,00 \mathrm{~d}$ \\
\hline
\end{tabular}

BNT $5 \%=22,07$

Keterangan: Angka yang diikuti oleh huruf yang sama pada kolom yang sama tidak berbeda nyata berdasarkan uji BNT pada $\alpha_{0,05}$.

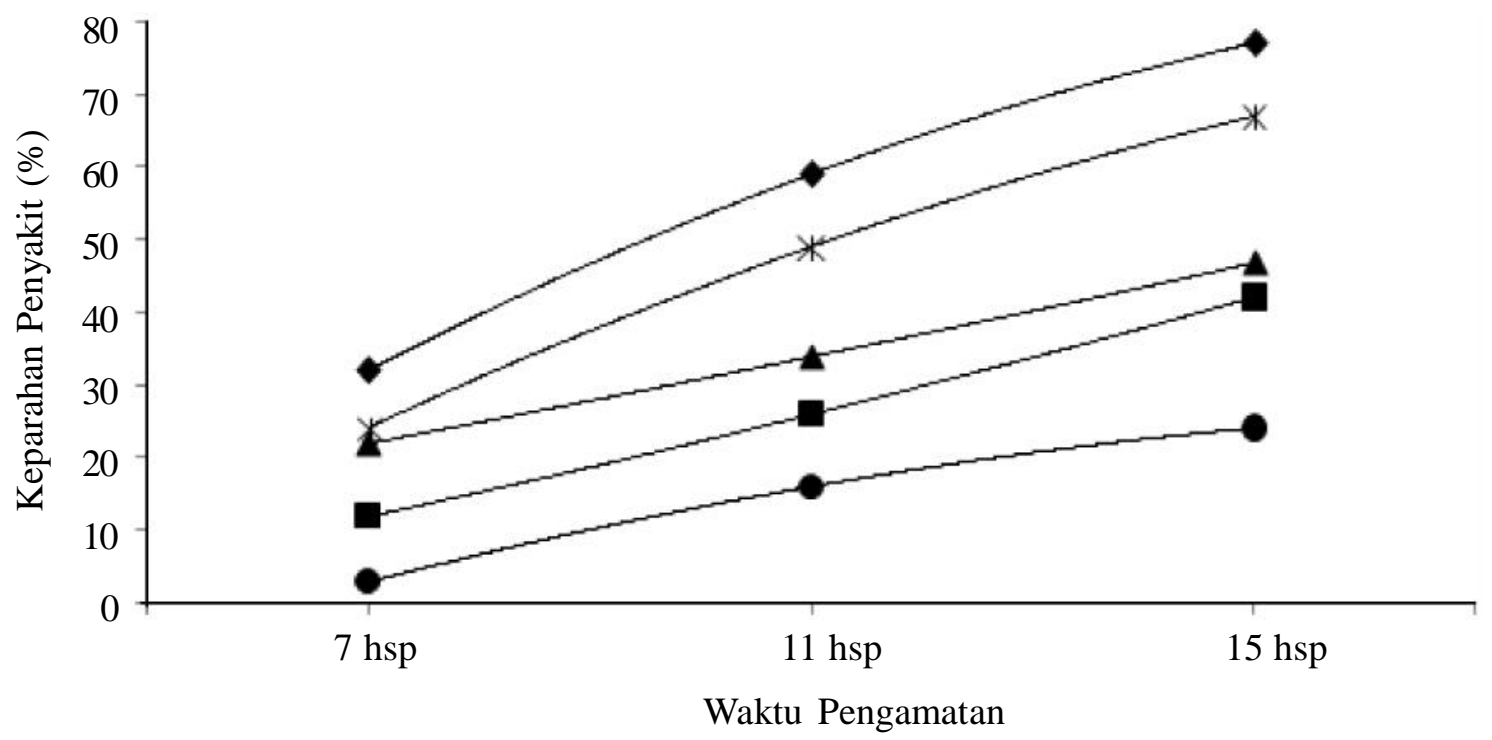

Gambar 2. Grafik perkembangan penyakit antraknosa pada buah cabai yang diberi beberapa perlakuan. $\bullet=\mathrm{P} 1$ (kontrol); $\boldsymbol{\square}=\mathrm{P} 2$ (kitosan); $\boldsymbol{\Lambda}=\mathrm{P} 3$ (kitosan+Trichoderma sp.); $*$ = P4 (Trichoderma sp.); $\bullet=$ P5 (kaptan).

melalui ikatan $\beta-(1,4)$, kemudian dilaporkan juga dari penelitian Ismail dan Tenrirawe (2012) bahwa cendawan Trichoderma spp. mempunyai kemampuan untuk menghasilkan enzim hidrolitik $\beta-1,3$ glukanase, kitinase dan selulase. Enzim-enzim inilah yang secara aktif merusak sel-sel jamur yang sebagian besar tersusun dari $\beta-1,3$ glukan (linamirin) dan kitin sehingga dengan mudah jamur Trichoderma spp. dapat melakukan penetrasi ke dalam hifa jamur inangnya.

Pada penelitian ini perlakuan kitosan dan kitosan +Trichoderma sp. dapat menekan perkembangan penyakit antraknosa pada buah cabai. Trichoderma sp. tidak dapat menekan perkembangan penyakit antraknosa karena ternyata jamur Trichoderma sp. yang diperoleh dari Laboratorium Balai Proteksi Tanaman Gadingrejo pada media PSA sudah berumur lama sehingga sifat mikoparasitiknya tidak efektif lagi, sedangkan pada penelitian Baharia (2000) yaitu Trichoderma spp. mampu menghambat pertumbuhan
C. capsici pada media PSA maupun pada buah cabai. Salah satu faktor yang menyebabkan pertumbuhan $C$. capsici terhambat karena cendawan Trichoderma spp. dapat mengeluarkan toksin yang menyebabkan terhambatnya pertumbuhan dan bahkan mematikan inangnya.

Dalam penelitian ini kitosan terbukti dapat menekan perkembangan penyakit antraknosa karena telah dilaporkan bahwa kitosan memiliki gugus aktif yang akan berikatan dengan mikroba sehingga kitosan mampu menghambat pertumbuhan mikroba dalam hal ini kitosan menghambat pertumbuhan Colletotrichum capsici jamur penyebab penyakit antraknosa (Hardjito, 2001). Laporan selanjutnya, terindikasikan bahwa ketika kitosan dilarutkan dalam garam, air suling, atau media laboratorium, menunjukkan aktivitas antimikrobial melawan strain-strain berfilamen dari fungi (dalam hal ini $C$. capsici), yeast dan bakteri (Rhoades dan Roller, 2000 dalam Winan, 2008). 
Kitosan tersebut merangsang akumulasi fitoaleksin jaringan tanaman inang, kitinase, $\beta$ glukanase, dan lipoksigenase (Vasyukova et al., 2001 dalam Sugipriatini, 2009). Kitosan juga dilaporkan efisien dalam pengendalian kebusukan buah-buahan pascapanen (Wang, 2007 dalam Sugipriatini, 2009).

\section{KESIMPULAN}

Dari penelitian ini dapat disimpulkan bahwa kitosan dan kitosan+Trichoderma sp. dapat menekan keparahan penyakit antraknosa pada buah cabai. Trichoderma sp. saja tidak dapat menekan keparahan penyakit antraknosa pada buah cabai dan kitosan sebanding dengan fungisida berbahan aktif kaptan dalam menekan keparahan penyakit antraknosa.

\section{DAFTAR PUSTAKA}

Baharia, S. 2000. Uji Antagonis Beberapa Isolat Cendawan Trichoderma terhadap Pertumbuhan Colletotrichum capsici pada Buah Cabai. Skripsi. Fakultas Pertanian UNTAD, Palu. 140 hlm.

Direktorat Perlindungan Tanaman Hortikultura. 2010. Pedoman Pengenalan dan Pengendalian Organisme Penggagnggu Tumbuhan Utama Pada Tanaman Cabai.Jakarta: Direktorat Jenderal Hortikultura, Departemen Pertanian. Jakarta. $156 \mathrm{hlm}$.

Efri, 2010. Pengaruh Ekstrak Berbagai Bagian Tanaman Mengkudu (Morinda citrifolia) terhadap Perkembangan Penyakti Antraknosa Pada Tanaman Cabe (Capsicum annuum L.). Jurnal HPT Tropika. 10(1): 52-58.

Istikorini, Y. 2002. Pengendalian Penyakit Tumbuhan Tecara Hayati yang Ekologis dan berkelanjutan. http://rudyct.com/PPS702ipb/05123/ yunik istikorini.htm. Diakses tanggal 5 November 2012.
Karyatiningsih, R. 1980. Pengamatan Penyakit pada Tanaman Jeruk di Kecamatan Wanaraja, Kabupaten Garut, Jawa Barat (laporan praktek lapang). Fakultas Pertanian, Institut Pertanian Bogor. Bogor.

Semangun, H. 1989. Penyakit-Penyakit Tanaman Hortikultura di Indonesia. Gadjah Mada University Press. Yogyakarta. 46-53 hlm.

Sugipriatini, D. 2009. Potensi Penggunaan Khamir dan Kitosan untuk Pengendalian Busuk Buah Lasiodiplodia theobromae (Pat.) Griffon \& Maubl. (syn. Botryodiplodia theobromae Pat.) pada Buah Mangga Selama Penyimpanan. Institut Pertanian Bogor. $57 \mathrm{hlm}$.

UPTD BPTPH. 2010. Laporan Tahunan 2010. Balai Proteksi Tanaman Pangan dan Hortikultura Provinsi Lampung. 24-26 hlm.

Winan. 2008. Chitin \&Chitosan. http:// winan 08.student.ipb.ac.id/2010/06/19/ chitinchitosan/. Diakses tanggal 10 Maret 2012.

Widodo, S.E., Zulferiyenni, dan Kusuma, D.W. 2013. Pengaruh Penambahan Benziladenin pada Pelapis Kitosan terhadap Mutu dan Masa Simpan Buah Jambu Biji 'CRYSTAL' . J. Agrotek Tropika 1(1):55-60.

Yusuf, T. 2010. Penyakit Penting Pada Tanaman Cabai. http://epetani.deptan.go.id/konsultasi/ cara-mengatasi-penyakit-pathek-pada-cabe 3283. Diakses tanggal 10 Mei 2012. 